\title{
Primary membranoproliferative glomerulonephritis
}

INSERM

\section{Source}

INSERM. (1999). Orphanet: an online rare disease and orphan drug data base. Primary membranoproliferative glomerulonephritis. ORPHA:54370

Membranoproliferative glomerulonephritis (MPGN) is a chronic progressive kidney disorder characterized by glomerular capillary wall structural changes and mesangial cell proliferation leading to nephrotic syndrome, hypocomplementemia, hypertension, proteinuria and end-stage kidney disease. MPGN can be due to either idiopathic (type 1, 2 and 3 MPGN; see these terms) or secondary (associated with infectious and immune complex diseases) causes. 